AGRICULTURE AND BIOLOGY JOURNAL OF NORTH AMERICA

ISSN Print: 2151-7517, ISSN Online: 2151-7525, doi:10.5251/abjna.2013.4.4.459.467

(C) 2013, ScienceHuß, http://www.scihub.org/ABJNA

\title{
Evaluation of the maturity of seeds from different sections of inflorescences of Amaranthus cruentus and Celosia argentea
}

\author{
A. O. Olufolaji ${ }^{1}$ and F.O. Odeleye ${ }^{2 *}$ \\ ${ }^{1}$ National Horticultural Research Institute (NIHORT), Jericho, Idi-Ishin, Ibadan \\ ${ }^{2}$ Dept. of Crop Protection \& Environmental Biology, University of Ibadan, Nigeria \\ * Corresponding author: gbengaodeleye2@yahoo.com \\ ABSTRACT
}

\begin{abstract}
Experiments were conducted in the screen house of National Horticultural Research Institute (NIHORT), Ibadan, Nigeria, to evaluate the level of germination and emergence of seeds from the different sections of inflorescences of two varieties each of Amaranthus (NHAc3, ED82/1040A) and Celosia (TLV8, Local green) chosen on the basis of maturity period. Seeds were taken from the basal, middle and top parts of the inflorescences of the varieties of these crops grown in the nursery. Seeds from whole inflorescence served as control. A split- plot design was used in which species served as main plot and inflorescence sections served as sub-plot with four replicates. Data were analyzed using SAS and LSD $(P=0.05)$. Results showed that there is distinct inflorescence maturity pattern for the two crops. The basal seeds germinated earlier and gave the highest seedling emergence while the apical seeds gave the lowest seedling emergence. Similarly, apical seeds of inflorescence gave root and plumule length that were $57 \%$ of those of the seedlings from the basal regions. Maturity of inflorescence was therefore acropetal in the crops. The determinate early flowering varieties of both species were significantly $(P=0.05)$ superior to the indeterminate late flowering ones in seedling emergence, plumule length as well as rooting depth. It seems therefore that early seedling growth which is better in the determinate early flowering varieties of Amaranthus and Celosia is a function of varietal differences as well as growth habit of the plant.
\end{abstract}

Keywords: Seedling emergence, plumule length, radicle length, inflorescence, Amaranthus, Celosia.

\section{INTRODUCTION}

Amaranthus cruentus and Celosia argentea are vegetables of considerable nutritional importance worldwide. The nutritional importance of Amaranths now attracts considerable attention in many countries especially when it was discovered that amaranths are cheap and rich sources of essential nutrients such as carotene, ascorbic acid, minerals and proteins (Oke, 1966, Olufolaji and Tayo, 1980; Sato et al. 2002). Besides, the amount of proteins in amaranth seed is of the same magnitude as that obtained in cow's milk $(16 \%)$ which is the standard of nutritional excellence(Bruce and Phillippe, 2007). In addition, the amount of proteins, vitamins and mineral in the leaf is a function of plant age and this is optimal at 57 weeks after sowing (Olufolaji and Tayo, 1980; Omueti, 1980; Culpeper-Stanley et al. 2006).

The nutritive quality of the seeds of grain amaranth is high. It can be milled to produce sweet, light coloured flour suitable for biscuits, bread, cakes and other confectioneries. The popped seeds are eaten as snack with milk and honey and it can also be served as sweet when held together with honey. These attributes show that seeds of Amaranthus offer good prospects for improving the protein content in the diet of people in the developing countries (Senft et al; 1982; Rezael et al 2009).

Viable seeds of Amaranthus usually germinate 3-4 days under field conditions. However, amaranth exhibit slow and irregular seedling emergence which might be due to the uneven maturity of the inflorescence which are spikes of racemes on the main stem (older) or on lateral branches (younger). This seed factor coupled with some environmental factors could cause irregular and poor emergence pattern of the crops to the extent that emergence could spread over a period of 14 days. This could also cause reduced plant vigor which might ultimately affect vegetable yields of these crops. In view of these, it is therefore justified to study how differences in the location of seeds within the inflorescence will 
Agric. Biol. J. N. Am., 2011, 4(4): 459-467

affect the germination and seedling establishment of Amaranthus and celosia which is the objective of the study reported herein.

\section{MATERIALS AND METHODS}

Seeds of varieties NHAc3 and ED82/1040A of Amaranthus, local green and TLV8 of Celosia representing early and late flowering types, respectively in each species were utilized in this study. These varieties of Amaranthus and Celosia were developed by the vegetable unit of NIHORT and are widely grown by vegetable farmers locally. Three nursery trials were carried out from November -December 2006 and January - April, 2007 to evaluate the level of germination and emergence of seeds from the different sections of the inflorescence of Amaranthus and Celosia. The experiments were carried out in the screen house of the National Horticultural Research Institute, (NIHORT) Ibadan, Nigeria.

In Celosia the inflorescence of mature TLV8 plants were separated into basal (Whitish-purple), middle (light-purple) and apical (deep-purple) sections, whereas those of mature local green" plants were separated into basal (grayish-white), middle (pinkishwhite) and apical (pinkish) sections. However, there were no distinct colour separation in the two varieties of Amaranthus so that each panicle was separated into three equal parts.

Four replicates of one hundred seeds from each section and a control (seeds from the whole inflorescence) were sown in the nursery trays using top-soil mixed with cured poultry droppings (in ratio $4: 1)$ as the medium. The plants were regularly watered as required. The temperature and relative humidity in the screen house were $28^{\circ} \mathrm{C}$ and $80 \%$ respectively. The rate of seedling emergence was assessed every other day for fourteen days. In addition, twenty seeds from each inflorescence section of each variety were sown in Petri-dishes lined with blotting paper. The rate of elongation of the radicle and plumule of each germinated seed was measured on a daily basis for fourteen days.

A split- plot design was used for the experiment in which the species served as the main plot, the inflorescence as the sub-plot. Data analysis was also done for each crop in which varieties served as the main plot and other experimental factors served as the sub-plot. In each experiment, there were four replications and records were taken of the rate of seedling emergence and establishment.

\section{RESULTS}

\section{Evaluation of the maturity of seeds from different sections of the Amaranthus and Celosia inflorescences}

\section{Amaranthus cruentus and Celosia argentea}

The effect of species, inflorescence section and their interaction on the percent seedling emergence and length of radicle and plumule of $A$. cruentus and $C$. Argentea are shown in Figs. 1-6. The percent seedling emergence in the trials was significantly higher in Amaranthus than in Celosia and averaged 62.5 and $54.8 \%$ respectively (Fig 1 ). The effects on $\%$ seedling emergence and plumule length in the species were highly significant $(\mathrm{P}=0.05)$ while that on the radicle length was also significant (Fig.2). The species $\mathrm{x}$ inflorescence section interaction was highly significant $(P=0.05)$ on radicle length but not significant for plumule length (Fig. 3)

Although Amaranthus produced longer radicles and plumules than celosia seedlings, the difference in radicle length was not significant $(P=0.05)$ in the three trials (Figs. 4 \&-5). However, the difference in plumule length were highly significant $(P=0.05)$ in all the trials. Interactions showed that on the average, seedlings from the basal part of Amaranthus and Celosia inflorescences had the longest radicle and pumule, at one week after sowing, while seedlings from the apical section had the shortest (Fig.6).

Amaranthus cruentus: The growth of radicle and plumule followed a similar trend. Variety NHAc3 had significantly $(P=0.05)$ longer radicles and plumules than ED82/1040A Tables 1, 2 \& 3. The seeds from the basal section had radicles and plumules that were superior in length to those of the middle section and the control, while the apical seeds gave the least performance. The variety $\mathrm{x}$ inflorescence section effects showed that seeds from basal section of NHAc3 had the longest radicles and pumules while the apical seed of ED82/1040A had the shortest (Tables 2 \& 3) percent seedling emergence was significantly higher in NHAc3 than in ED82/1040A. Seeds from the basal section of the inflorescence gave the highest percent seedling emergence while seeds from the apical section gave the least. 


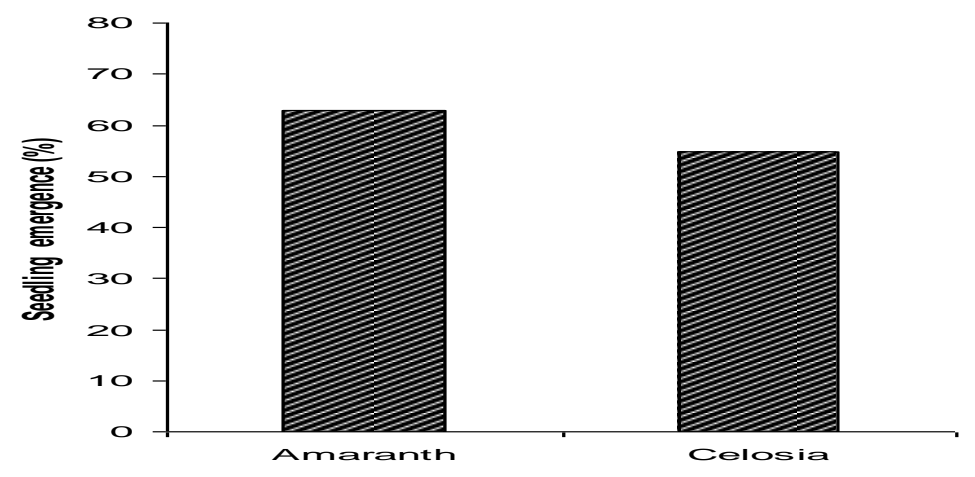

Fig. 1 Effect of species on \% seedling emergence. I=LSD ( $P=0.05)$

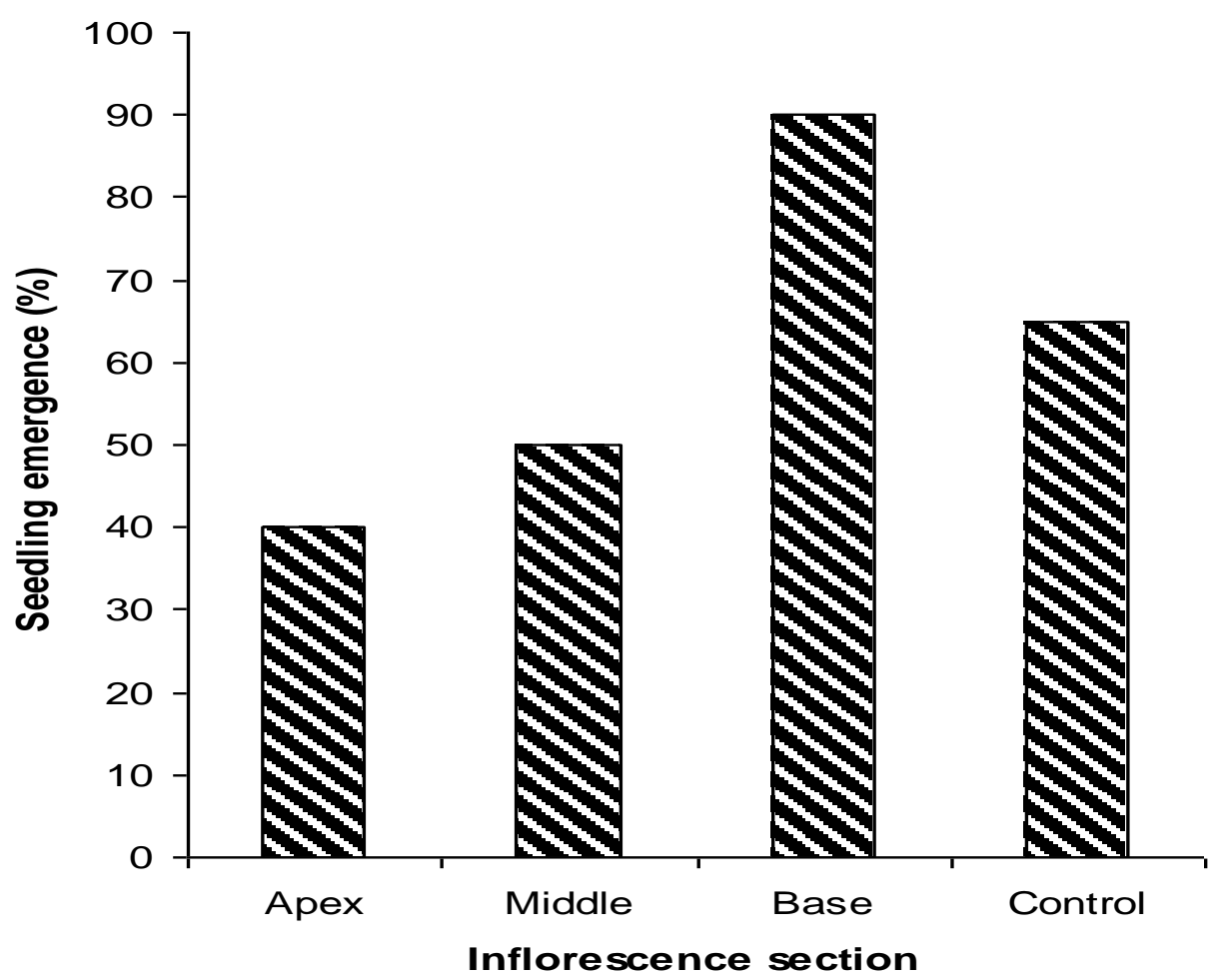

Fig.2. Effect of inflorescence section on \% seedling emergence. I= LSD $(P=0.05)$ 


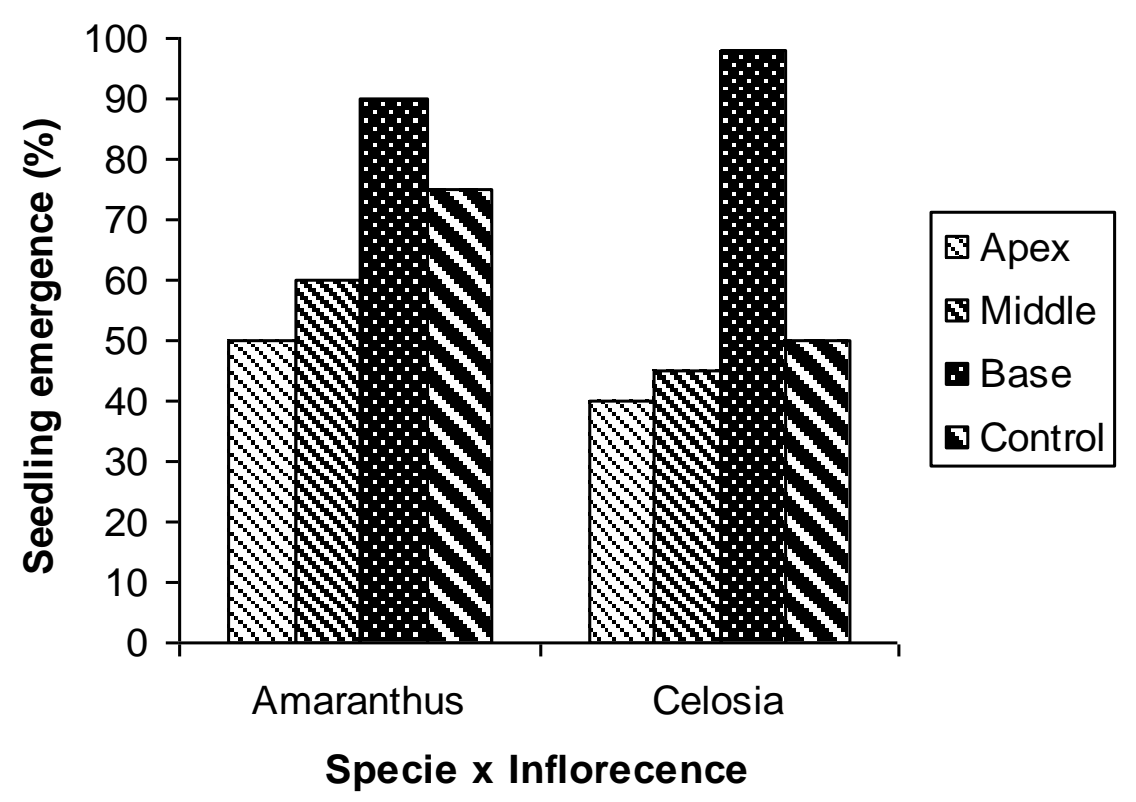

Fig. 3 Effect of species $x$ inflorescence section on seedling emergence. I=LSD ( $P=0.05)$
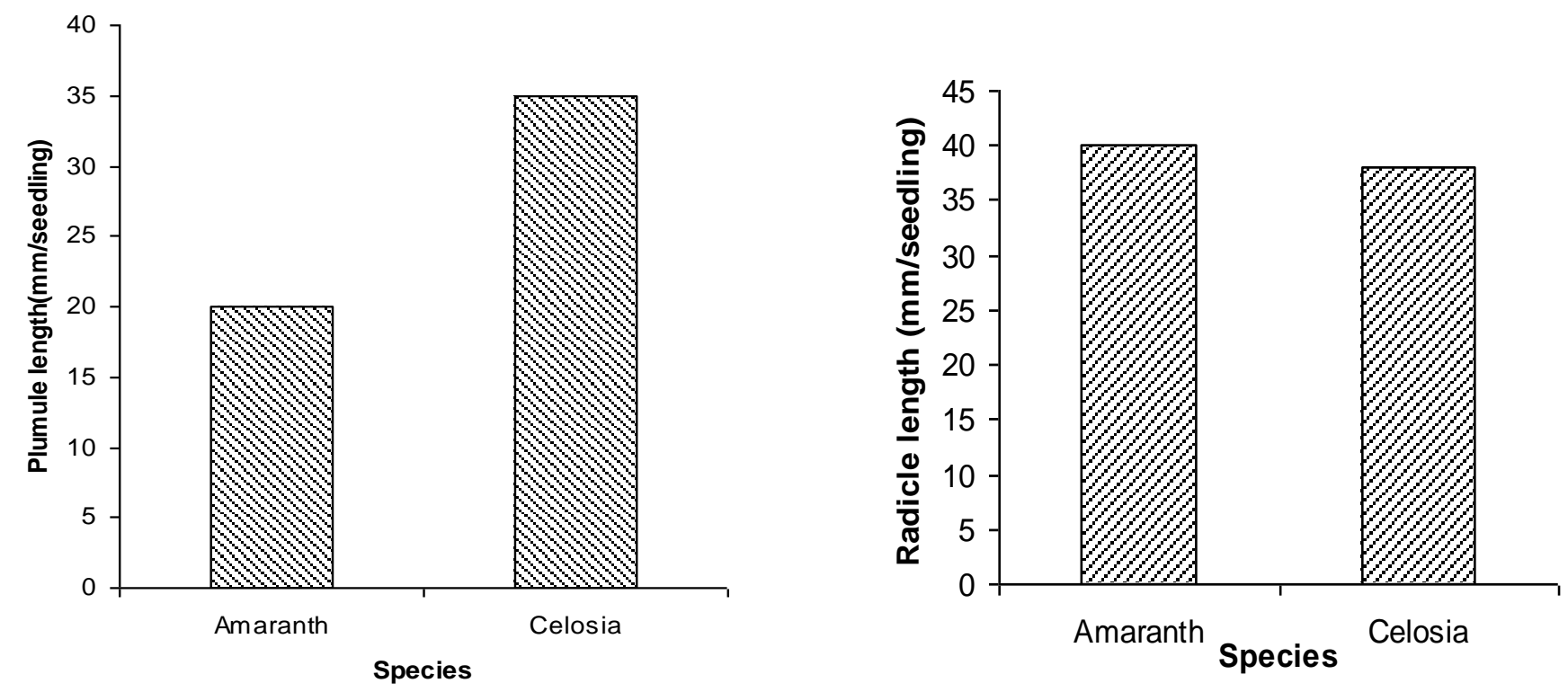

Fig. 4 Effect of species on plumule and radicle length of $A$. cruentus and $C$. argentea I= LSD $(P=0.05)$ 
Agric. Biol. J. N. Am., 2011, 4(4): 459-467
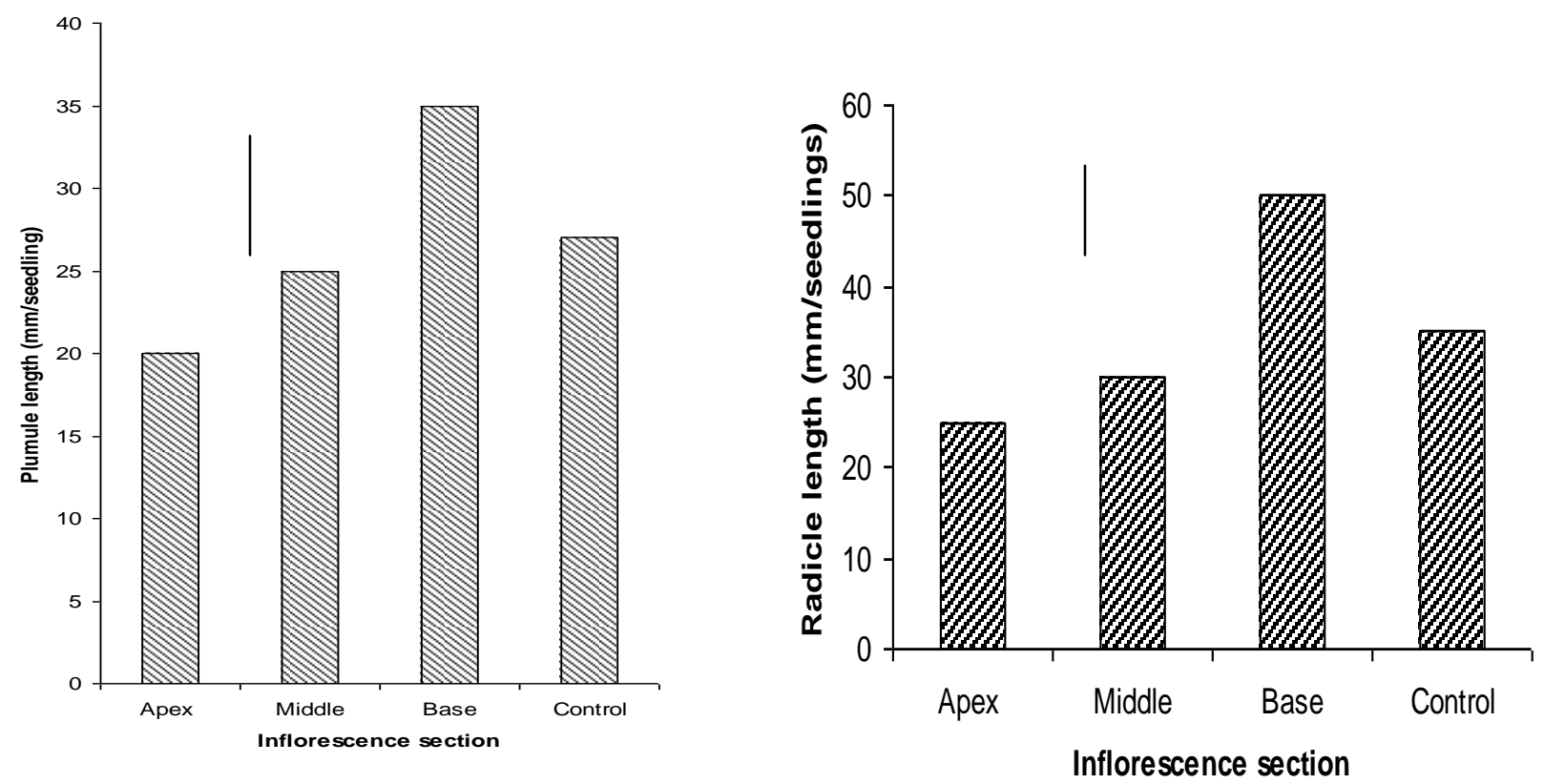

Fig. 5.Effect of inflorescence section on plumule and radicle length of $A$. cruentus and C. argentea, I= LSD $(P=0.05)$.
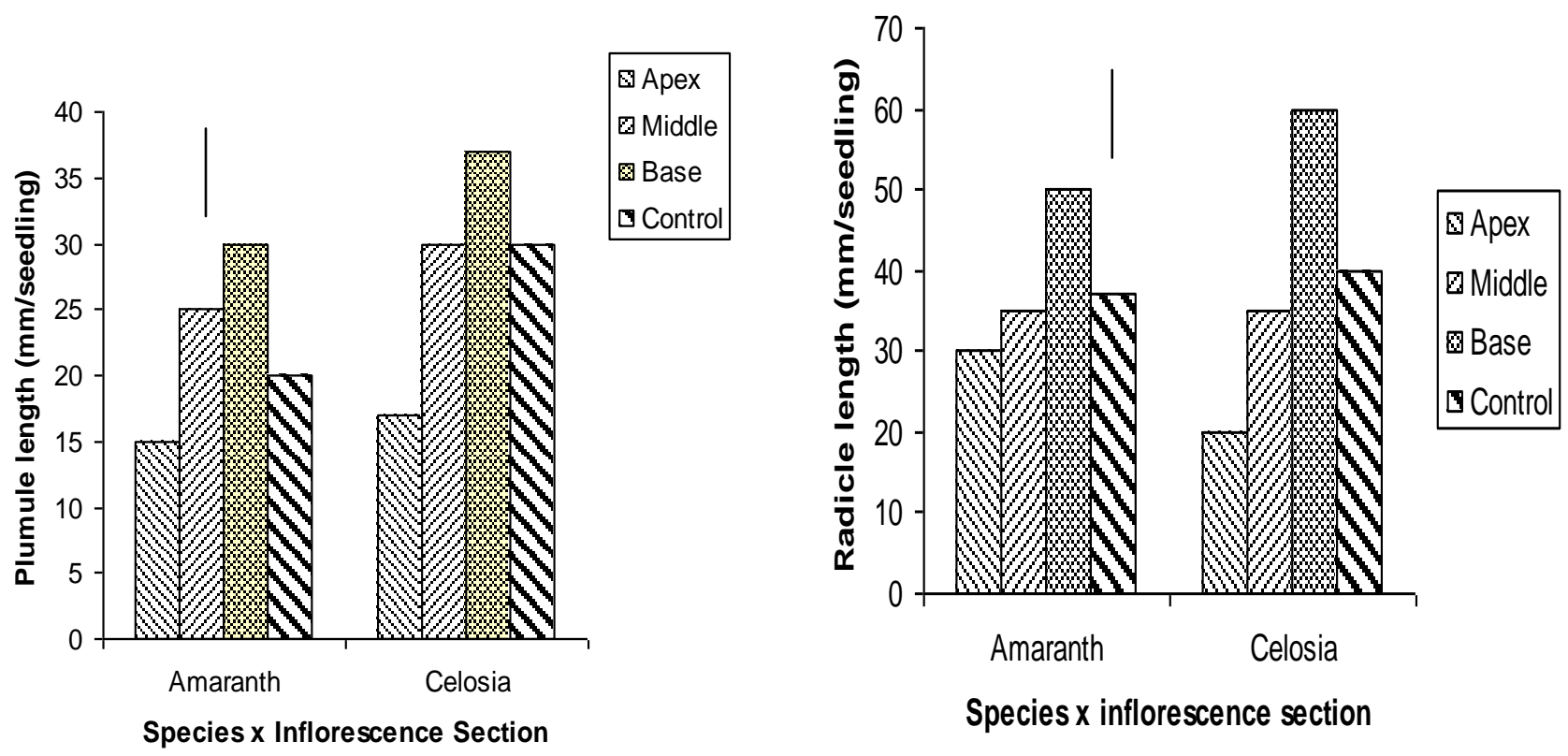

Fig. 6 Effect of species $\mathrm{x}$ inflorescence section on lengths of plumule and radicle of $A$. cruentus and $C$. argentea, I= $\operatorname{LSD}(\mathrm{P}=0.05)$ 
Table 1 Mean values of the \% seedling emergence of seeds from different sections of Amaranthus inflorescence

\begin{tabular}{|l|l|l|l|l|}
\hline \multicolumn{5}{|c|}{ Trials } \\
\hline $\begin{array}{l}\text { Treatment } \\
\text { Variety }\end{array}$ & $1^{\text {st }}$ & $2^{\text {nd }}$ & $3^{\text {Id }}$ & Means \\
\hline NHAc3 & 67.9 & 68.9 & 68.1 & 68.3 \\
\hline ED82/1040A & 53.9 & 62.5 & 53.4 & 56.6 \\
\hline L.S.D. (P=0.05) & 7.58 & 4.52 & 3.80 & 2.88 \\
\hline Inflorescence & & & & \\
\hline $\begin{array}{l}\text { Apical } \\
\text { Inflorescence }\end{array}$ & 45.3 & 41.6 & 43.6 & 43.5 \\
\hline $\begin{array}{l}\text { Middle } \\
\text { Inflorescence }\end{array}$ & 60.1 & 62.0 & 56.6 & 59.6 \\
\hline $\begin{array}{l}\text { Basal } \\
\text { Inflorescence }\end{array}$ & 76.6 & 92.5 & 81.3 & 83.5 \\
\hline $\begin{array}{l}\text { Control } \\
\text { Inflorescence }\end{array}$ & 61.6 & 66.6 & 61.5 & 63.3 \\
\hline LSD (P=0.05) & 3.92 & 4.04 & 2.89 & 2.32 \\
\hline Interactions & & & & \\
\hline Apex NHAc3 & 48.8 & 54.8 & 57.3 & 53.6 \\
\hline $\begin{array}{l}\text { Apex } \\
\text { ED82/1040A }\end{array}$ & 41.8 & 28.5 & 30.0 & 33.4 \\
\hline Middle NHAc3 & 69.8 & 63.0 & 69.0 & 67.3 \\
\hline $\begin{array}{l}\text { Middle } \\
\text { ED82/1040A }\end{array}$ & 50.5 & 61.0 & 44.3 & 51.9 \\
\hline Base NAAc3 & 84.3 & 92.3 & 79.0 & 85.2 \\
\hline $\begin{array}{l}\text { Base } \\
\text { ED82/1040A }\end{array}$ & 69.0 & 92.8 & 83.3 & 81.7 \\
\hline Control NHAc3 & 68.8 & 65.5 & 30.0 & 54.8 \\
\hline $\begin{array}{l}\text { Control } \\
\text { ED82/1040A }\end{array}$ & 54.5 & 67.8 & 56.0 & 59.4 \\
\hline LSD (P=0.05) & 5.55 & 5.71 & 4.09 & 5.12 \\
\hline & & & & \\
\hline
\end{tabular}

Celosia argentea: In the first two trials, the two varieties of Celosia gave similar percent emerged seedlings while in the third, and as indicated by the pooled mean, local green was superior to TLV8 in the percent emerged seedling (Table 4). Percent seedling emergence was highest when seeds from the basal section were sown and lowest in seeds from the apical section of inflorescence. The effects of variety $x$ inflorescence section combination showed that the basal seeds of both varieties produced the highest percent seedling emergence while the apical seeds of TLV8 gave the lowest (Table 4).
Table 2 Mean values of radicle length ( $\mathrm{mm}$ seedling ${ }^{-1}$ ) of seed from different sections of Amaranthus inflorescence

\begin{tabular}{|c|c|c|c|c|}
\hline & \multicolumn{3}{|c|}{ Trials } & \multirow[b]{2}{*}{ Means } \\
\hline $\begin{array}{l}\text { Treatment } \\
\text { Variety }\end{array}$ & $1 \mathrm{st}$ & 2nd & 3rd & \\
\hline NHAC3 & 47.3 & 48.8 & 36.5 & 44.2 \\
\hline ED82/1040A & 33.3 & 40.5 & 26.5 & 33.4 \\
\hline LSD $(P=0.05)$ & 2.33 & 2.28 & 1.98 & 2.19 \\
\hline \multicolumn{5}{|l|}{ Inflorescence } \\
\hline $\begin{array}{l}\text { Apical } \\
\text { inflorescence }\end{array}$ & 22.4 & 29.0 & 24.1 & 25.2 \\
\hline $\begin{array}{l}\text { Middle } \\
\text { inflorescence }\end{array}$ & 40.3 & 46.4 & 32.1 & 39.6 \\
\hline $\begin{array}{l}\text { Basal } \\
\text { inflorescence }\end{array}$ & 58.3 & 58.5 & 38.9 & 51.9 \\
\hline $\begin{array}{l}\text { Control } \\
\text { inflorescence }\end{array}$ & 40.3 & 44.8 & 30.9 & 38.6 \\
\hline LSD CP $=0.05$ & 3.50 & 3.31 & 1.59 & 2.84 \\
\hline \multicolumn{5}{|l|}{ Interactions } \\
\hline Apex NHAC 3 & 29.0 & 29.8 & 29.3 & 29.3 \\
\hline $\begin{array}{l}\text { Apex } \\
\text { ED82/1040A }\end{array}$ & 15.8 & 28.3 & 19.0 & 23.0 \\
\hline Middle NHAc3 & 51.5 & 54.8 & 37.5 & 47.9 \\
\hline $\begin{array}{l}\text { Middle } \\
\text { ED82/1040A }\end{array}$ & 29.0 & 38.0 & 26.8 & 31.3 \\
\hline Base NHAc3 & 60.8 & 60.0 & 43.5 & 54.8 \\
\hline Base ED82/1040 & 55.8 & 57.0 & 34.3 & 49.0 \\
\hline Control NHAc3 & 48.0 & 50.8 & 35.8 & 44.9 \\
\hline $\begin{array}{l}\text { Control } \\
\text { ED82/1040A }\end{array}$ & 32.5 & 38.8 & 26.0 & 32.4 \\
\hline LSD $(P=0.05)$ & 4.96 & 4.67 & 2.26 & 3.96 \\
\hline
\end{tabular}

The early local green variety was superior to TLV8 in radicle and plumule lengths in the three trials (Tables 5 \& 6). Seeds from the basal section produced significantly $(P=0.05)$ longer radicles and plumules than seeds from all other sections including the control. The radicles and plumules from the middle section and the control seeds were however superior to those from the apical section. Consequently, seeds from the basal section of local green inflorescence produced the longest radicles and plumules, while the apical seeds of TLV8 inflorescence produced the shortest (Tables 5 \& 6). 
Agric. Biol. J. N. Am., 2011, 4(4): 459-467

Table 3 Mean values of plumule length ( $\mathrm{mm}$ seeding ${ }^{-1}$ ) of seeds from different sections of Amaranthus inflorescence

\begin{tabular}{|l|l|l|l|l|}
\hline & \multicolumn{3}{|c|}{ Trials } & \\
\hline $\begin{array}{l}\text { Treatment } \\
\text { Variety }\end{array}$ & 1 st & 2nd & 3rd & Means \\
\hline NHAC3 & 32.1 & 34.3 & 40.1 & 35.5 \\
\hline ED82/1040A & 29.1 & 31.4 & 27.9 & 30.1 \\
\hline LSD (P=0.05) & 1.87 & 0.98 & 0.68 & 1.18 \\
\hline Inflorescence & & & & \\
\hline $\begin{array}{l}\text { Apical } \\
\text { inflorescence }\end{array}$ & 24.8 & 24.6 & 26.9 & 25.4 \\
\hline $\begin{array}{l}\text { Middle } \\
\text { inflorescence }\end{array}$ & 30.0 & 32.9 & 34.9 & 32.6 \\
\hline $\begin{array}{l}\text { Basal } \\
\text { inflorescence }\end{array}$ & 37.8 & 41.6 & 43.4 & 40.9 \\
\hline $\begin{array}{l}\text { Control } \\
\text { inflorescence }\end{array}$ & 29.8 & 32.3 & 34.8 & 32.3 \\
\hline LSD CP =0.05 & 1.93 & 1.39 & 1.89 & 1.74 \\
\hline Interactions & & & & \\
\hline Apex NHAC 3 & 24.0 & 25.9 & 33.8 & 27.9 \\
\hline $\begin{array}{l}\text { Apex } \\
\text { ED82/1040A }\end{array}$ & 25.5 & 23.4 & 20.0 & 22.9 \\
\hline Middle NHAc3 & 31.8 & 33.9 & 40.5 & 36.7 \\
\hline $\begin{array}{l}\text { Middle } \\
\text { ED82/1040A }\end{array}$ & 28.3 & 31.9 & 29.3 & 29.8 \\
\hline Base NHAc3 & 42.0 & 42.0 & 48.5 & 44.2 \\
\hline $\begin{array}{l}\text { Base } \\
\text { ED82/1040 }\end{array}$ & 33.5 & 41.2 & 38.3 & 37.7 \\
\hline Control NHAc3 & 30.5 & 35.5 & 37.5 & 34.5 \\
\hline $\begin{array}{l}\text { Control } \\
\text { ED82/1040A }\end{array}$ & 29.0 & 29.0 & 32.0 & 30.0 \\
\hline LSD (P=0.05) & 2.73 & 1.96 & 2.69 & 2.46 \\
\hline
\end{tabular}

Table 4 Mean values of the \% seedling emergence of seeds from different sections of Celosia Varieties' inflorescence

\begin{tabular}{|l|l|l|l|l|}
\hline \multicolumn{2}{|l|}{} & \multicolumn{5}{|c|}{ Trials } & \\
\hline $\begin{array}{l}\text { Treatment } \\
\text { variety }\end{array}$ & 1 st & 2nd & 3 rd & Means \\
\hline TLV8 & 49.1 & 61.1 & 47.9 & 52.7 \\
\hline Local green & 48.8 & 69.5 & 53.1 & 56.9 \\
\hline LSD (P=0.05) & 3.49 & 13.29 & 4.81 & 4.15 \\
\hline Inflorescence & & & & \\
\hline $\begin{array}{l}\text { Apex } \\
\text { inflorescence }\end{array}$ & 22.0 & 40.6 & 29.8 & 30.8 \\
\hline $\begin{array}{l}\text { Middle } \\
\text { inflorescence }\end{array}$ & 53.5 & 63.4 & 40.4 & 52.4 \\
\hline $\begin{array}{l}\text { Basal } \\
\text { inflorescence }\end{array}$ & 64.1 & 91.3 & 86.3 & 80.6 \\
\hline $\begin{array}{l}\text { Control } \\
\text { inflorescence }\end{array}$ & 56.0 & 65.7 & 45.8 & 55.8 \\
\hline LSD CP =0.05 & 3.39 & 5.86 & 4.95 & 2.65 \\
\hline Interactions & & & & \\
\hline Apex TLV8 & 20.8 & 34.0 & 27.8 & 27.5 \\
\hline Apex Local green & 23.3 & 47.3 & 31.8 & 34.1 \\
\hline Middle TLV8 & 53.5 & 56.0 & 36.9 & 48.8 \\
\hline $\begin{array}{l}\text { Middle } \\
\text { green }\end{array}$ & 53.5 & 70.8 & 44.0 & 58.1 \\
\hline Base TLV8 & 65.3 & 93.0 & 87.8 & 82.0 \\
\hline Base Local green & 63.0 & 90.0 & 84.8 & 79.3 \\
\hline Control TLV8 & 56.8 & 61.5 & 39.5 & 52.6 \\
\hline $\begin{array}{l}\text { Control } \\
\text { green }\end{array}$ & 55.3 & 69.9 & 52.0 & 59.1 \\
\hline LSD (P=0.05) & 4.79 & 8.29 & 6.99 & 6.69 \\
\hline
\end{tabular}


Table 5 Mean values of the radicle length $(\mathrm{mm}$ seedling $\left.{ }^{1}\right)$ of seeds from different sections of Celosia inflorescence

\begin{tabular}{|c|c|c|c|c|}
\hline & \multicolumn{3}{|r|}{ Trials } & \multirow[b]{2}{*}{ Means } \\
\hline $\begin{array}{l}\text { Treatment } \\
\text { Variety }\end{array}$ & $1 \mathrm{st}$ & 2nd & 3rd & \\
\hline TLV8 & 33.8 & 30.2 & 28.4 & 30.8 \\
\hline Local green & 40.5 & 40.5 & 32.7 & 37.9 \\
\hline $\operatorname{LSD}(\mathrm{P}=0.05)$ & 1.31 & 1.57 & 1.39 & 1.25 \\
\hline \multicolumn{5}{|l|}{ Inflorescence } \\
\hline $\begin{array}{l}\text { Apical } \\
\text { inflorescence }\end{array}$ & 30.5 & 27.0 & 25.0 & 27.5 \\
\hline $\begin{array}{l}\text { Middle } \\
\text { inflorescence }\end{array}$ & 34.5 & 35.1 & 31.5 & 33.7 \\
\hline $\begin{array}{l}\text { Basal } \\
\text { inflorescence }\end{array}$ & 47.1 & 45.5 & 36.5 & 43.0 \\
\hline $\begin{array}{l}\text { Control } \\
\text { inflorescence }\end{array}$ & 36.5 & 33.8 & 29.1 & 33.1 \\
\hline LSD CP $=0.05$ & 2.61 & 2.88 & 2.20 & 3.45 \\
\hline \multicolumn{5}{|l|}{ Interactions } \\
\hline Apex TLV8 & 28.5 & 21.8 & 22.3 & 24.2 \\
\hline $\begin{array}{ll}\text { Apex } & \text { Local } \\
\text { green } & \\
\end{array}$ & 32.5 & 32.3 & 27.8 & 30.9 \\
\hline Middle TLV8 & 30.3 & 30.3 & 30.5 & 30.4 \\
\hline $\begin{array}{ll}\text { Middle Local } \\
\text { green }\end{array}$ & 38.8 & 40.0 & 32.5 & 37.1 \\
\hline Base TLV8 & 41.8 & 39.3 & 34.3 & 38.5 \\
\hline Base Local green & 52.5 & 51.8 & 38.8 & 47.7 \\
\hline Control TLV8 & 34.8 & 29.5 & 26.5 & 30.3 \\
\hline $\begin{array}{l}\text { Control Local } \\
\text { green }\end{array}$ & 38.3 & 38.0 & 31.8 & 36.0 \\
\hline LSD $(P=0.05)$ & 3.69 & 4.07 & 3.11 & 3.62 \\
\hline
\end{tabular}

\section{DISCUSSION}

The results of this study indicate that there is a distinct inflorescence maturity pattern for the two crops. The variability in the rate and overall percent germination of seeds from different sections of the inflorescence could be due to differential maturity of seed embryo or sometimes due to incomplete filling of the seed. Seeds with immature embryo remain viable but dormant even under favourable conditions of germination, until the embryo matures, while seeds that are not completely filled during maturation usually do not germinate. It is best therefore to cut off the apical parts of the inflorescence to avoid seeds from this section when preserving the seeds to be used in the next planting season. It is also possible to minimize this problem if a breeding program could be set up to look into the possibility of ensuring uniform maturity of seeds from all the sections of the inflorescence.
Table 6. Mean values of plumule length $\left(\mathrm{mm}\right.$ seedling $\left.{ }^{-1}\right)$ of seeds from different sections of Celosia inflorescence

\begin{tabular}{|c|c|c|c|c|}
\hline & \multicolumn{3}{|r|}{ Trials } & \multirow[b]{2}{*}{ Means } \\
\hline $\begin{array}{l}\text { Treatment } \\
\text { Variety }\end{array}$ & $1 \mathrm{st}$ & 2nd & $3 r d$ & \\
\hline TLV8 & 18.1 & 18.3 & 18.9 & 18.4 \\
\hline Local green & 22.9 & 24.8 & 21.5 & 23.1 \\
\hline LSD $(P=0.05)$ & 2.21 & 0.98 & 1.05 & 1.4 \\
\hline \multicolumn{5}{|l|}{ Inflorescence } \\
\hline $\begin{array}{l}\text { Apical } \\
\text { inflorescence }\end{array}$ & 13.8 & 15.3 & 10.8 & 13.3 \\
\hline $\begin{array}{l}\text { Middle } \\
\text { inflorescence }\end{array}$ & 21.4 & 21.2 & 19.6 & 20.7 \\
\hline $\begin{array}{l}\text { Basal } \\
\text { inflorescence }\end{array}$ & 26.9 & 28.4 & 29.5 & 28.3 \\
\hline $\begin{array}{l}\text { Control } \\
\text { inflorescence }\end{array}$ & 20 & 21.4 & 20.9 & 20.8 \\
\hline LSD CP $=0.05$ & 2.33 & 1.56 & 2.14 & 2.01 \\
\hline \multicolumn{5}{|l|}{ Interactions } \\
\hline Apex TLV8 & 11.0 & 11.3 & 9.8 & 10.7 \\
\hline $\begin{array}{ll}\text { Apex } & \text { Local } \\
\text { green } & \\
\end{array}$ & 16.5 & 19.4 & 11.8 & 15.9 \\
\hline Middle TLV8 & 17.5 & 17.2 & 18.8 & 17.8 \\
\hline $\begin{array}{l}\text { Middle Local } \\
\text { green }\end{array}$ & 25.3 & 25.2 & 20.5 & 23.9 \\
\hline Base TLV8 & 26.0 & 25.0 & 27.3 & 26.1 \\
\hline Base Local green & 27.8 & 31.8 & 31.8 & 30.5 \\
\hline Control TLV8 & 18.0 & 19.9 & 19.8 & 19.2 \\
\hline $\begin{array}{l}\text { Control Local } \\
\text { green }\end{array}$ & 22.3 & 22.8 & 22.0 & 22.4 \\
\hline LSD $(P=0.05)$ & 3.29 & 2.20 & 3.03 & 2.84 \\
\hline
\end{tabular}

The pattern of inflorescence maturity could probably be acropetal since the basal (which appeared to be the onset of seed maturity) germinated earlier and gave the highest seedling emergence while the apical which seems to be the terminal and of seed maturity with low rate of germination) gave the least percent seedling emergence. Thus sowing seeds from the appropriate section of the inflorescence of any variety would ensure maximum seedling emergence. Harvesting of the seed should be aimed at the time when the basal and middle inflorescence sections are mature. The process should not be left until the whole (basal, middle and apical) inflorescence are fully mature as this results in seed dropping and a significant reduction in seed yield.

Comparing the two species, Amaranthus seeds emerged earlier and produced longer radicles than the seeds of celosia thereby indicating that a parallel relationship exists between the time of germination and length of radicle. Similarly, seedlings from the 
apical region had root and plumule length that were only about $57 \%$ of those of the seedlings from the basal regions. It is probable that root and plumule lengths are manifestations of the earliness of germination because seeds from the basal region germinated earlier and produced longer roots and plumule than the apical ones. This agrees with the report of Barbour (1968) that longer roots are indicative of the speed of germination. In addition, Oladiran and Mumford (1985) reported that large (more mature) Amaranthus seeds germinated earlier and produced longer seedlings than small seeds.

Celosia seeds are bigger and therefore probably contain more food reserves than Amaranthus seeds; at one week after sowing, celosia seedlings were shorter but sturdier and more upright than Amaranthus while the ratio of root/seedling length averaged $54 \%$ and $62 \%$ in both varieties each of Amaranthus and Celosia, respectively. These physical and quantitative differences could contribute to the higher percentage of establishment of celosia seedlings than Amaranthus. Mayer and PolkajoffMayber (1975) reported that seedling establishment could only be effected when the germinating seeds establish anchorage by the roots to ensure commencement of water and solute absorption from the soil.

The determinate early flowering varieties of both species were superior to the indeterminate late flowering varieties, in seedling emergence as well as rooting depth. It seems therefore that early seedling growth which is better in the determinate early flowering varieties of celosia and Amaranthus is a function of varietal differences as well as growth habit of the plant. This is in line with the findings of Olufolaji (1980) that up till 7 weeks after sowing, the absolute growth rate of Amaranthus and Celosia (which is a measure of seedling vigour) is significantly better in the early flowering varieties than in the late ones.

\section{REFERENCES}

Barbour, M.G. (1968). Germination requirements of the Desert Shrub ( Larrea divaricata). Ecology 49: 915-923
Culpepper-Stanley, A., Timothy L. Grey, William, K Vencell, Jeremy M. Kichler, Theodore M. Webster, Steve M. Brown, Alan C. York, Jerry W. Davis and Wayne W. Hanna (2006). Glyphosate-resistant Palmer amaranth (Amaranthus palmer) confirmed in Georgia. Weed Science 54 (4): 620-626

Bruce Gelinas and Phillippe Seguin 2007. Oxalate in Grain Amaranth J. Agric. Food Chemistry 55 (12): 4789-4794

Mayer, A.M. and Poljakoff-Mayber, A. 1975. The germination of seeds. $2^{\text {nd }}$ Edition. Printed by Pargomon Press Oxford, Vol. 5, 192pp

Oke, O.L. 1966 Chemical studies on the more commonly used vegetables in Nigeria J.W. Afr.. Sci. Ass. 2: 4248

Oladiran, J.A. and Mumford, P.M. 1985. A study of the effect of seed size on seed longevity and seedling size in Amaranthus gangetions and $A$. hybridus. A paper presented at the $7^{\text {th }}$ Annual Conference of the Horticultural Society of Nigeria, held at ASCON, Badagry, Lagos. August, $4^{\text {th }}-8^{\text {th }}$.

Olufolaji, A.O. 1980. Effect of varieties, spacings and fertilizer on the growth and development of Amaranthus spp and Celosia argentea. M.Phil. Disssertation, University of Ibadan, Nigeria. 130pp

Olufolaji. A.O. and Tayo, T.O. 1980. Growth, development and mineral contents of three cultivals of amaranth. Scienctia Horticulture, 13:181 - 189.

Omueti, O. (1980). Effects of age of Celosia cultivars. Expl Agric. 16: 279-286.

Rezael, J., Rouzbehan,F. and Fazael, H. 2009 Nutritive value of fresh and ensiled amaranth (Amaranthus hypochondriacus) treated with different levels of Molasses. Animal feed Science \& technology 151 (1) : 153-160

Sato, T., Nagata, M and Engle, L.M. 2002 Evaluation of antioxidant activity of indigenous vegetables from south and south east Asia. JIRCAS Research Highlights 2002 (Japan International Research Center for Agricultural Sciences: 102-108

Senft, J.P., Kauffman, C.S. and Barley, N.N. 1982. Amaranth Bibliography In: maranth Newsletter No 1, March, 1983 58pp 